Article

\title{
Production and Characterization of Anti-Inflammatory Monascus Pigment Derivatives
}

\author{
Deokyeong Choe ${ }^{1,2,+}$, Soo Min Song ${ }^{3,+}$, Chul Soo Shin ${ }^{3}$, Tony V. Johnston ${ }^{1}{ }^{\mathbb{C}}$, Hyung Jin Ahn ${ }^{4}$, \\ Daehwan Kim ${ }^{5, *(D)}$ and Seockmo Ku ${ }^{1, *(D)}$ \\ 1 Fermentation Science Program, School of Agriculture, College of Basic and Applied Sciences, \\ Middle Tennessee State University, Murfreesboro, TN 37132, USA; deokyeong.choe@mtsu.edu (D.C.); \\ tony.johnston@mtsu.edu (T.V.J.) \\ 2 Department of Biochemistry and Cancer Biology, Meharry Medical College, Nashville, TN 37208, USA \\ 3 Department of Biotechnology, College of Life Science and Biotechnology, Yonsei University, \\ Seoul 03722, Korea; soomini16@nate.com (S.M.S.); csshin@yonsei.ac.kr (C.S.S.) \\ 4 Department of Food and Nutrition, Research Institute of Human Ecology, Seoul National University, \\ Seoul 08826, Korea; ahnjin2000@snu.ac.kr \\ 5 Department of Biology, Hood College, Frederick, MD 21701, USA \\ * $\quad$ Correspondence: kimd@hood.edu (D.K.); seockmo.ku@mtsu.edu (S.K.); Tel.: +1-301-696-3287 (D.K.); \\ +1-615-904-8290 (S.K.) \\ + These authors contributed equally to the work.
}

Received: 1 June 2020; Accepted: 18 June 2020; Published: 1 July 2020

\begin{abstract}
The prevention and treatment of chronic inflammation using food-derived compounds are desirable from the perspectives of marketing and safety. Monascus pigments, widely used as food additives, can be used as a chronic inflammation treatment. Orange Monascus pigments were produced by submerged fermentation in a $5 \mathrm{~L}$ bioreactor, and multiple orange Monascus pigment derivatives with anti-inflammatory activities were synthesized using aminophilic reaction. A total of 41 types of pigment derivatives were produced by incorporating amines and amino acids into the orange pigments. One derivative candidate that inhibited nitric oxide (NO) production in Raw 264.7 cells and exhibited low cell cytotoxicity was identified via in vitro assay. The 2 -amino- 4 picoline derivative inhibited NO production of $48.4 \%$, and exhibited cell viability of $90.6 \%$. Expression of inducible NO synthase, an important enzyme in the NO synthesis pathway, was suppressed by such a derivative in a dose-dependent manner. Therefore, this derivative has potential as a functional food colorant with anti-inflammatory effects.
\end{abstract}

Keywords: amine derivatives; amino acid derivatives; anti-inflammatory effects; submerged fermentation; orange Monascus pigments

\section{Introduction}

Inflammation is a protective response of the body to noxious stimuli, such as infection, tissue injury, and irritants [1-3]. It plays a role in eliminating the initial cause of cell injury, protecting cells from the spread of infection, initiating tissue repair, and restoring tissue function $[4,5]$. However, chronic inflammation, which is a prolonged abnormal inflammatory response [6], can cause many diseases including cancer, diabetes, cardiovascular disease, autoimmune disease, osteoarthritis, depression, and Alzheimer's disease [7-9]. The World Health Organization (WHO) has reported that the greatest threat to public health is chronic inflammation and its associated diseases [10]. Moreover, $60 \%$ of the global mortality rate is attributed to chronic inflammatory diseases [11].

To overcome the problem of chronic inflammation, various types of anti-inflammatory drugs have been developed, and studies on newer anti-inflammatory drugs are ongoing. Anti-inflammatory drugs 
(e.g., glucocorticoids) are one of the effective approaches to treating chronic inflammation, but prolonged or high-dose glucocorticoid therapy has multiple side effects [12]. With these safety concerns, natural foods with anti-inflammatory properties have received attention as alternative strategies for the prevention and treatment of chronic inflammation. Alleviating inflammation and strengthening the immune system are the main benefits of anti-inflammatory foods such as probiotics, blueberry, tomato, avocado, salmon, olive oil, garlic, ginger, green tea, almond, spinach, oat, broccoli, and onion [13-15]. The increasing interest in anti-inflammatory foods has also boosted research on natural functional pigments with anti-inflammatory effects because such pigments can be used as food coloring agents, in addition. The best-known examples of natural functional pigments with anti-inflammatory properties are quercetin [16,17], curcumin [18,19], anthocyanin [20,21], and Monascus pigments [22,23].

Monascus pigments, which are microbial colorants, are secondary metabolites produced by the fermentation of edible Monascus species fungi [24,25]. Monascus pigments are a complex mixture of compounds with an azaphilone skeleton, which is a class of a typical fungal polyketide pigment [26,27]. Monascus pigments have been used as food additives in Asian countries for thousands of years [28]. They are traditionally classified as red, orange, and yellow pigments based on their maximum absorbance [29]. Among these three colors, orange pigments can be transformed into Monascus pigment derivatives by aminophilic reaction [30]. Specifically, pyranyl oxygen in orange pigments is replaced with a primary amine such as a protein, peptide, amino sugar, amino alcohol, or nucleic acid, and subsequent derivatives with red color are formed [31]. In recent years, various derivatives of orange pigments have been produced with amines and amino acids in our laboratory. These derivatives have exhibited a variety of biological properties, such as antimicrobial activity [32], hepatitis C virus replication inhibition [33], anti-atherosclerosis effects [34], diet-related lipase and $\alpha$-glucosidase inhibitory activities [35], cholesteryl ester transfer protein inhibitory activity [36], obesity inhibitory activity [37], and melanogenesis inhibition [38]. However, to the best of our knowledge, there are few reports on the evaluation of Monascus pigment derivatives for anti-inflammatory effects.

In this study, orange Monascus pigments produced through submerged fermentation were converted to various amine and amino acid derivatives through bioprocessing. One Monascus pigment derivative that strongly inhibits nitric oxide (NO) production in cells and shows low cytotoxicity was selected. Its inhibitory effect was further analyzed for the expression of an enzyme involved in the inflammatory response.

\section{Materials and Methods}

\subsection{Materials}

Amines, amino acids, silica gel, fetal bovine serum (FBS), lipopolysaccharide (LPS), 3-(4,5-dimethylthiazol2-yl)-2,5-diphenyltetrazolium bromide (MTT), protease inhibitor cocktail (P2714), and dimethyl sulfoxide (DMSO) were purchased from Sigma-Aldrich Co. (St. Louis, MO, USA). Ethyl acetate, n-hexane, ethanol, methanol, acetonitrile, potassium hydrogen phosphate, potassium dihydrogen phosphate, sodium nitrate, magnesium sulfate heptahydrate, iron(II) sulfate heptahydrate, sodium hydroxide, hydrochloric acid, acetic acid, potassium chloride, sodium chloride, sucrose, glucose, and agar powder were purchased from Duksan Co. (Seoul, Korea). Ammonium nitrate was purchased from Samchun Chemicals Co. (Seoul, Korea). Bacto-peptone, casamino acid, and yeast extract were purchased from BD Difco (Franklin Lakes, NJ, USA). Raw 264.7 cells (a murine macrophage cell line) were obtained from the Korea Cell Line Bank (Seoul, Korea). Dulbecco's modified Eagle medium (DMEM) were purchased from Gibco (Grand Island, NY, USA). Antibodies for inducible nitric oxide synthase (iNOS) and $\alpha$-tubulin were purchased from Santa Cruz Biotechnology, Inc. (Dallas, TX, USA). Reagents for Western blotting were purchased from ELPIS Biotechnology (Seoul, Korea). Griess reagent was purchased from Promega (Madison, WI, USA). 


\subsection{Cells and Media}

Monascus sp. KCCM 10093 (Korea Culture Center for Microorganisms; Seoul, Korea) was used to produce orange Monascus pigments. The strain was preserved on a slant of Hiroi agar medium, which consisted of sucrose $(100 \mathrm{~g} / \mathrm{L})$, casamino acid $(5 \mathrm{~g} / \mathrm{L})$, yeast extract $(3 \mathrm{~g} / \mathrm{L}), \mathrm{NaNO}_{3}(2 \mathrm{~g} / \mathrm{L})$, $\mathrm{KH}_{2} \mathrm{PO}_{4}(1 \mathrm{~g} / \mathrm{L}), \mathrm{MgSO}_{4} \cdot 7 \mathrm{H}_{2} \mathrm{O}(0.5 \mathrm{~g} / \mathrm{L}), \mathrm{KCl}(0.5 \mathrm{~g} / \mathrm{L}), \mathrm{FeSO}_{4} \cdot 7 \mathrm{H}_{2} \mathrm{O}(0.01 \mathrm{~g} / \mathrm{L})$, and agar powder $(20 \mathrm{~g} / \mathrm{L})$ in distilled water. Mizutani medium for spore culture consisted of glucose $(50 \mathrm{~g} / \mathrm{L})$, Bacto-peptone $(20 \mathrm{~g} / \mathrm{L}), \mathrm{KH}_{2} \mathrm{PO}_{4}(8 \mathrm{~g} / \mathrm{L}), \mathrm{CH}_{3} \mathrm{COOH}(2 \mathrm{~g} / \mathrm{L}), \mathrm{NaCl}(1 \mathrm{~g} / \mathrm{L})$, and $\mathrm{MgSO}_{4} \cdot 7 \mathrm{H}_{2} \mathrm{O}(0.5 \mathrm{~g} / \mathrm{L})$ in distilled water. The fermentation culture medium for orange pigment production consisted of glucose $(50 \mathrm{~g} / \mathrm{L})$, $\mathrm{NH}_{4} \mathrm{NO}_{3}(3 \mathrm{~g} / \mathrm{L}), \mathrm{KH}_{2} \mathrm{PO}_{4}(1 \mathrm{~g} / \mathrm{L}), \mathrm{MgSO}_{4} \cdot 7 \mathrm{H}_{2} \mathrm{O}(0.5 \mathrm{~g} / \mathrm{L}), \mathrm{KCl}(0.5 \mathrm{~g} / \mathrm{L})$, and $\mathrm{FeSO}_{4} \cdot 7 \mathrm{H}_{2} \mathrm{O}(0.01 \mathrm{~g} / \mathrm{L})$ in distilled water. All media were adjusted to $\mathrm{pH} 6.6$ prior to sterilization.

Raw 264.7 cells were used to evaluate the inhibitory activities of Monascus pigment derivatives against nitric oxide (NO) production. The cell growth medium consisted of DMEM (phenol red-free) supplemented with streptomycin $(100 \mu \mathrm{g} / \mathrm{mL})$, penicillin $(100 \mathrm{U} / \mathrm{mL})$, and $10 \% \mathrm{FBS}$.

\subsection{Procedures for Monascus Cultivation}

For the preparation of spore suspensions, Monascus sp. KCCM 10093 was grown on Hiroi agar slants for 7 days at $30^{\circ} \mathrm{C}$. After $10 \mathrm{~mL}$ of sterilized distilled water was added to each slant, spores were scraped off using a sterile spatula. For the spore culture, spore suspensions were inoculated into $500 \mathrm{~mL}$ Sakaguchi flasks containing $75 \mathrm{~mL}$ of sterilized Mizutani medium, followed by incubation for $48 \mathrm{~h}$ on a reciprocal shaking water bath at $30^{\circ} \mathrm{C}$ and $120 \mathrm{rpm}$. For the seed culture, the spore culture broth was inoculated at $7 \%(v / v)$ into $500 \mathrm{~mL}$ Sakaguchi flasks containing $75 \mathrm{~mL}$ of sterilized Mizutani medium, followed by incubation for $24 \mathrm{~h}$ on a reciprocal shaking water bath at $30^{\circ} \mathrm{C}$ and $120 \mathrm{rpm}$. For the fermentation culture, the seed culture broth was inoculated at $7 \%(v / v)$ into a $5 \mathrm{~L}$ bioreactor containing $3 \mathrm{~L}$ of a sterilized fermentation medium. Cultivations were performed for $120 \mathrm{~h}$ at $30^{\circ} \mathrm{C}$ and $500 \mathrm{rpm}$ with an aeration rate of $1.0 \mathrm{vvm}$.

\subsection{Extraction and Identification of Orange Pigments}

To extract orange pigments, $3 \mathrm{~L}$ of fermentation broth was filtered with Whatman filter paper (No. 4), and the filter cake was mixed with $2 \mathrm{~L}$ of ethyl acetate. The mixture was incubated for $48 \mathrm{~h}$ on a reciprocal shaking water bath at $30^{\circ} \mathrm{C}$ and $150 \mathrm{rpm}$. After separating the ethyl acetate layer containing orange pigments, the solution was condensed to about $100 \mathrm{~mL}$ using a rotary evaporator (N-1110V-WD, Eyela Rikakikai Company, Tokyo, Japan) at a constant temperature of $70{ }^{\circ} \mathrm{C}$. Approximately $200 \mathrm{~g}$ of silica gel powder was added to the solution for the adsorption of pigments. The pigment-silica gel complex was mixed with $1 \mathrm{~L}$ of $\mathrm{n}$-hexane, followed by incubation at room temperature for $10 \mathrm{~h}$. The hexane layer containing impurities was then removed. This n-hexane treatment was repeated five times. For the dissolution of the pigment, $1 \mathrm{~L}$ of ethyl acetate was added to the pigment-silica gel complex, and the ethyl acetate layer containing orange pigments was filtered with Whatman filter paper (No. 4) to remove the residual silica gel. Ethyl acetate was removed from the solution using a rotary evaporator (N-1110V-WD, Eyela Rikakikai Company, Tokyo, Japan) at a constant temperature of $70{ }^{\circ} \mathrm{C}$, and orange pigments were obtained in solid form.

Identification of the orange pigments was performed in accordance with our previous methods [36,39]. The orange pigments were analyzed by HPLC and LC-MS. An HPLC (Acme 9000, Younglin Instrument, Seoul, Korea) with a GOLD C18 column (Hypersil, $250 \times 4.6 \mathrm{~mm}$ and $5 \mu \mathrm{m}$ ) was operated with a run time of $60 \mathrm{~min}$, flow rate of $1.25 \mathrm{~mL} / \mathrm{min}$, and elution ratio of distilled water/acetonitrile of 40:60 (v/v). An LC-MS (UPLC-LTQ-Orbitrap XL, Thermo Fisher Scientific, Waltham, MA, USA) with an Acquity UPLC BEH C18 column $(50 \times 2.1 \mathrm{~mm}$ and $1.7 \mu \mathrm{m})$ was operated with a run time of $18 \mathrm{~min}$, flow rate of $0.3 \mathrm{~mL} / \mathrm{min}$, and elution ratio of $0.1 \%$ formic acid/acetonitrile of $40: 60(\mathrm{v} / \mathrm{v})$. The mass spectrometer was operated in the ESI-positive mode, and the spray voltage was $5 \mathrm{kV}$. The capillary voltage, tube lens voltage, and capillary temperature were $35 \mathrm{~V}, 100 \mathrm{~V}$, and $370{ }^{\circ} \mathrm{C}$, respectively. 


\subsection{Determination of Cell Mass, Dissolved Oxygen Tension, $p H$, and Orange Pigment Production}

To measure the cell mass, culture broths were filtered through Whatman filter paper $(110 \Phi$, No. 4$)$ and washed with distilled water to remove culture debris. Cell concentrations were calculated after the filter papers were incubated in a drying oven (FO-600M, Jeio Tech., Daejeon, Korea) for $24 \mathrm{~h}$ at $80^{\circ} \mathrm{C}$. Dissolved oxygen tension (DOT) was measured using a DO probe (D100, Broadley-James Corp., Irvine, $\mathrm{CA}, \mathrm{USA}$ ). The $\mathrm{pH}$ was measured using a $\mathrm{pH}$ probe (F-615, Broadley-James Corp., Irvine, CA, USA). The concentration of orange pigments was measured by HPLC (Acme 9000, Younglin Instrument, Seoul, Korea).

\subsection{Procedures for the Synthesis of Monascus Pigment Derivatives}

The synthesis of Monascus pigment derivatives was performed in accordance with our previous methods $[31,38]$. Orange pigments, amines, and amino acids were individually dissolved in ethanol. Equal volumes of orange pigment solution and nitrogenous solution (amine or amino acid solution) were mixed together, and the mixture was agitated with a vortexer, followed by incubation at $60{ }^{\circ} \mathrm{C}$ for $1 \mathrm{~h}$. In the case of amino acid derivatives, potassium phosphate buffer $(3 \mathrm{M}, \mathrm{pH}$ 9.7) was added to the mixture to promote the synthesis reaction. After the completion of the reaction, the buffer was removed from the derivative solution through layer separation. Thus, 21 amine derivatives and 20 amino acid derivatives were synthesized (Table 1 and Figure 1a).

Table 1. Amines and amino acids used for synthesis of Monascus pigment derivatives.

\begin{tabular}{cccc}
\hline Derivative Compound & Amines & Derivative Compound & Amino Acids \\
\hline D1 & 2-amino-6-methylpyridine & D22 & Serine \\
D2 & 2-amino-4-picoline & D23 & Threonine \\
D3 & Cysteine \\
D4 & 5,6,7,8-tetrahydro-2-naphthylamine & D24 & Dethionine \\
D5 & 2-amino-5-bromopyridine & D26 & Asparagine \\
D6 & 1-amino-4-methylpiperazine & D27 & Glutamine \\
D7 & 2-amino-4-chlorophenol & D28 & Aspartic acid \\
D8 & 2-amino-5-methylthiazole & D29 & Glutamic acid \\
D9 & 2-amino-5-chlorophenol & D30 & Lysine \\
D10 & 2-amino-4-fluorophenol & D31 & Arginine \\
D11 & 2-amino-5-iodopyridine & D32 & Histidine \\
D12 & 4-amino-4H-1,2,4-triazole & D33 & Phenylalanine \\
D13 & Methyl-d -amine hydrochloride & D34 & Tyrosine \\
D14 & (R)-(-)-1-amino-2-propanol & D35 & Tryptophan \\
D15 & (S)-(+)-1-amino-2-propanol & D36 & Glycine \\
D16 & 5,6,7,8-tetrahydro-4H- & D37 & Alanine \\
D17 & cyclohepta[d][1,3]thiazol-2-amine & Valine \\
D18 & Benzylamine & D38 & Leucine \\
D19 & 4-methylphenethylamine & D39 & Isoleucine \\
D20 & 4-aminotetrahydropyran & D40 & Theanine \\
D21 & (R)-(-)-2-amino-1-butanol & D41 & \\
\hline
\end{tabular}




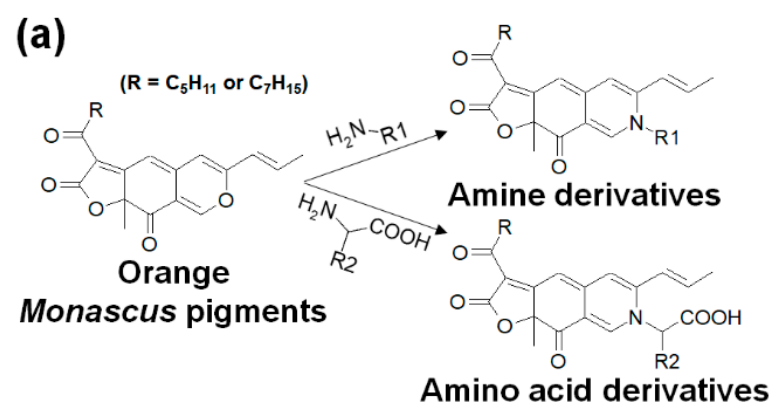

(b)

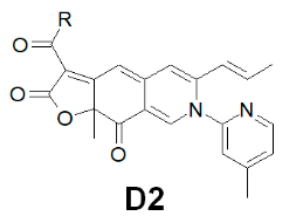

Figure 1. Synthesis of amine and amino acid derivatives from orange Monascus pigments (a) and the molecular structure of the 2-amino-4-picoline (D2) derivative of Monascus pigment (b).

\subsection{Measurement of NO Concentration}

Raw 264.7 cells were maintained in DMEM (phenol red-free) supplemented with streptomycin $(100 \mu \mathrm{g} / \mathrm{mL})$, penicillin $(100 \mathrm{U} / \mathrm{mL})$, and $10 \% \mathrm{FBS}$, and cultivated at $37^{\circ} \mathrm{C}$ in a humidified incubator with $5 \% \mathrm{CO}_{2}$. To assess the NO levels, nitrite concentration was measured as an indicator of NO production. Raw 264.7 cells $\left(2 \times 10^{5} /\right.$ well) were plated and treated with LPS $(10 \mu \mathrm{g} / \mathrm{mL})$ in the presence or absence of Monascus pigment derivatives $(20 \mu \mathrm{M})$. After incubation for $18 \mathrm{~h}$, the suspended media were collected. The nitrite concentration in the culture medium was measured using a Griess reaction. A total of $100 \mu \mathrm{L}$ of the sample supernatants was mixed with $100 \mu \mathrm{L}$ of the Griess reagent (1\% sulfanilamide in $5 \%$ phosphoric acid and $0.1 \%$ naphthylethylenediamine dihydrochloride in water). Absorbance of the mixture at $560 \mathrm{~nm}$ was determined using a microplate reader. After preparing a standard curve using $\mathrm{NaNO}_{3}$, the nitrite concentration was determined by comparing the value of absorbance.

\subsection{MTT Assay for Cell Viability}

The cell viability of Monascus pigment derivatives was measured using an MTT assay. Raw 264.7 cells were seeded in 96-well plates $\left(2 \times 10^{5} /\right.$ well $)$ and incubated for $24 \mathrm{~h}$ in a humidified $5 \% \mathrm{CO}_{2}$ incubator at $37^{\circ} \mathrm{C}$. The derivatives $(20 \mu \mathrm{M})$ were added into the wells, and the plates were incubated for $24 \mathrm{~h}$. For the control, the derivative was not added. After supernatants were removed, $100 \mu \mathrm{L}$ of MTT solution $(1 \mathrm{mg} / \mathrm{mL})$ was added to the cells. The plates were incubated for $3 \mathrm{~h}$, followed by the removal of the MTT solution. Then, $100 \mu \mathrm{L}$ of DMSO was added to the wells to dissolve formazan. The absorbance was determined using a microplate reader at a wavelength of $560 \mathrm{~nm}$.

\subsection{Western Blot Analysis}

Raw 264.7 cells $\left(2 \times 10^{5}\right.$ /well) were lysed with a radio-immunoprecipitation assay buffer containing protease and phosphatase inhibitors on ice for $10 \mathrm{~min}$. The lysates were centrifuged at $13,800 \times g$ for $20 \mathrm{~min}$. The protein concentration of the cell lysates was determined using Bradford reagent. The samples were subjected to sodium dodecyl sulfate-polyacrylamide gel electrophoresis (SDS-PAGE) for $2 \mathrm{~h}$ and transferred to the nitrocellulose membranes for $2 \mathrm{~h}$. The membranes were blocked with $5 \%$ non-fat milk in Tris-buffered saline with $1 \%$ Tween 20 (TBST). After washing with TBST, the membranes were incubated with primary antibodies specific for iNOS and $\alpha$-tubulin at $4{ }^{\circ} \mathrm{C}$ overnight, followed by washing with TBST. Blots were probed with goat anti-rabbit immunoglobulin $\mathrm{G}$ conjugated to peroxidase for $1 \mathrm{~h}$. Immunoreactive bands were detected by an electrochemiluminescence detection system (Syngene, Cambridge, UK). 


\section{Results and Discussion}

\subsection{Production of Orange Monascus Pigments through Submerged Fermentation}

To synthesize Monascus pigment derivatives, their basic building blocks, orange Monascus pigments, are required. As red and yellow Monascus pigments are not involved in the aminophilic reaction for the synthesis of Monascus pigment derivatives [30], maximizing the yield of orange pigments by suppression of the production of red and yellow pigments during the whole process is an adequate approach. To achieve this goal, inorganic ammonic compounds (e.g., ammonium nitrate, $\mathrm{NH}_{4} \mathrm{NO}_{3}$ ) as a nitrogen source for Monascus fermentation were used in our previous studies [31,39,40]. However, there are few reports on the effects of ammonium nitrate on the production of orange pigments and on the submerged culture of Monascus sp. KCCM 10093. Investigating these effects was perceived to provide useful information to improve the productivity of orange pigments, so we evaluated cell mass, DOT, $\mathrm{pH}$, and orange pigment yield by monitoring a 5 L bioreactor at $24 \mathrm{~h}$ intervals for 5 days (Figure 2).

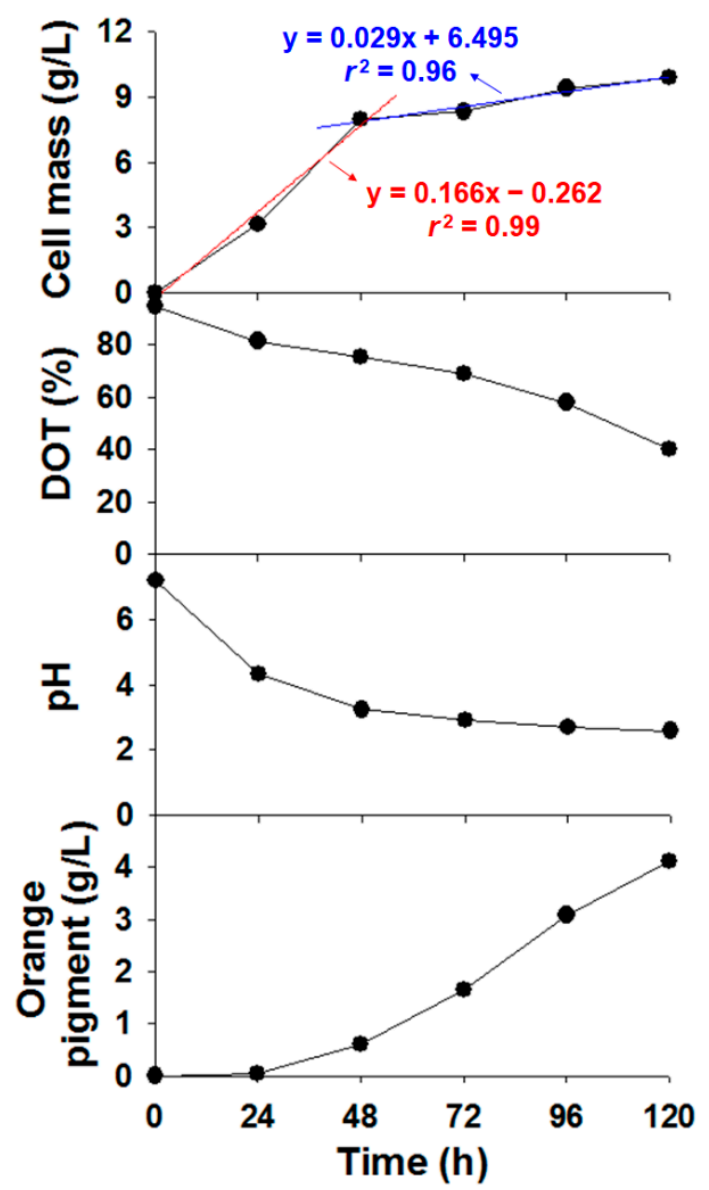

Figure 2. Production profiles of orange Monascus pigments in a $5 \mathrm{~L}$ bioreactor. DOT = dissolved oxygen tension.

Cell mass rapidly increased up to $8.0 \mathrm{~g} / \mathrm{L}$ within $48 \mathrm{~h}$ and continuously increased for $120 \mathrm{~h}$, showing a final cell concentration of $9.9 \mathrm{~g} / \mathrm{L}$. With increasing cell mass, DOT consistently decreased from $95 \%$ to $40 \%$, indicating that oxygen was almost uniformly consumed during the whole fermentation process. Aerobic microorganisms require an abundance of oxygen for cell growth during the log phase, whereas continuous oxygen consumption was observed during the whole fermentation process for the production of orange pigments. This result implies that oxygen is necessary not only for cell growth but also for orange pigment production. Indeed, the production of orange pigments was reported to be reduced by the limitation of dissolved oxygen [41], and an improvement in oxygen supply led 
to an increase in Monascus pigments [42-44]. In addition, oxygen is a substrate of a flavin adenine dinucleotide-dependent monooxygenase, which is involved in a biosynthetic pathway for orange pigments $[29,45,46]$. Therefore, we suggest that oxygen is one of main factors in the production of orange pigments through submerged fermentation.

Unlike the observation of continuous oxygen consumption, the growth rates (red and blue lines in Figure 2), which are the change in the cell mass per unit time, were considerably different before and after $48 \mathrm{~h}$. This difference was probably due to the change in $\mathrm{pH}$. The $\mathrm{pH}$ values were $7.2,4.3$, $3.2,2.9,2.7$, and 2.6 at $0,24,48,72,96$, and $120 \mathrm{~h}$, respectively. In other words, the initial $\mathrm{pH}$ of 7.2 rapidly decreased by 3.2 units within $48 \mathrm{~h}$ and then further decreased by 2.6 more units. Such pH reduction was caused by ammonium nitrate [47]. When ammonium $\left(\mathrm{NH}_{4}^{+}\right)$salts are added as a nitrogen source, Monascus sp. assimilates ammonia $\left(\mathrm{NH}_{3}\right)$ and releases protons $\left(\mathrm{H}^{+}\right)$, leading to acidification of the culture broth [48]. Low $\mathrm{pH}$ can play a role in the inhibition of cell growth, as the preferred $\mathrm{pH}$ for Monascus cell growth is 5.5-6.5 [44,49]. In contrast to growth rates, the synthesis of orange pigments was promoted by low $\mathrm{pH}$. For the $0-48 \mathrm{~h}$ period showing a high growth rate and high $\mathrm{pH}$, the orange pigment yield was $0.6 \mathrm{~g} / \mathrm{L}$. For the $48-120 \mathrm{~h}$ period showing a low growth rate and low $\mathrm{pH}$, the production of orange pigments rapidly increased and the final yield reached $4.1 \mathrm{~g} / \mathrm{L}$ at $120 \mathrm{~h}$ (Figure 2). This result is in agreement with previous reports in which large amounts of orange pigments were obtained under acidic fermentation conditions [50,51], red pigments were mainly produced at $\mathrm{pH} 6.5$, and orange pigments were observed in $\mathrm{pH} 2.5$ media [44,49]. The increase in orange pigment yield under low-pH conditions can be caused by inhibition of the transformation of orange to red pigments [28,52]. As red pigments are known to be synthesized by amination reaction from orange pigments $[29,52]$, inhibition of this transformation can result in a substantial increase in orange pigments during the fermentation process. Furthermore, at low $\mathrm{pH}$, a significant increase in the expression of key enzyme-coding genes related to the biosynthesis of orange pigments, such as MrpigA, MrpigB, MrpigF, MrpigJ, and MrpigK, has been reported [50]. Their increased expression contributed to the enhancement in orange pigment yields. Consequently, the use of ammonium nitrate as a nitrogen source for Monascus fermentation reduced the $\mathrm{pH}$, leading to enhanced production of orange pigments.

\subsection{Preparation Process for Orange Monascus Pigments and Synthesis of Derivatives}

Orange Monascus pigments produced through submerged fermentation were extracted, condensed, separated, and purified in the presence of ethyl acetate, n-hexane, or silica gel (Figure 3). When the fermentation was completed, a mixture of culture broth, mycelia, and orange pigments was obtained from the $5 \mathrm{~L}$ bioreactor. As orange pigments are insoluble in water due to their hydrophobicity [30,53], they were separated from the culture broth by filtration, which resulted in the creation of filter cakes laden with orange pigments. To extract the orange pigments from the filter cakes, a solvent with a polarity suitable for dissolving the orange pigments was required. Of the organic solvents permitted for use in the food industry (methanol, ethanol, ethyl acetate, acetone, and n-hexane) [54], ethyl acetate has been used for the extraction of orange pigments in previous studies $[55,56]$. Orange pigments are highly soluble in ethyl acetate, an amphiphilic volatile organic solvent. It can effectively extract the targeted orange pigments without chemical changes and/or damage to the pigments. Moreover, ethyl acetate is generally recognized as safe (GRAS) for use in beverages and foods as a flavoring agent and adjuvant [57]. For these reasons, ethyl acetate was selected as the extraction solvent for orange pigments in this study. 


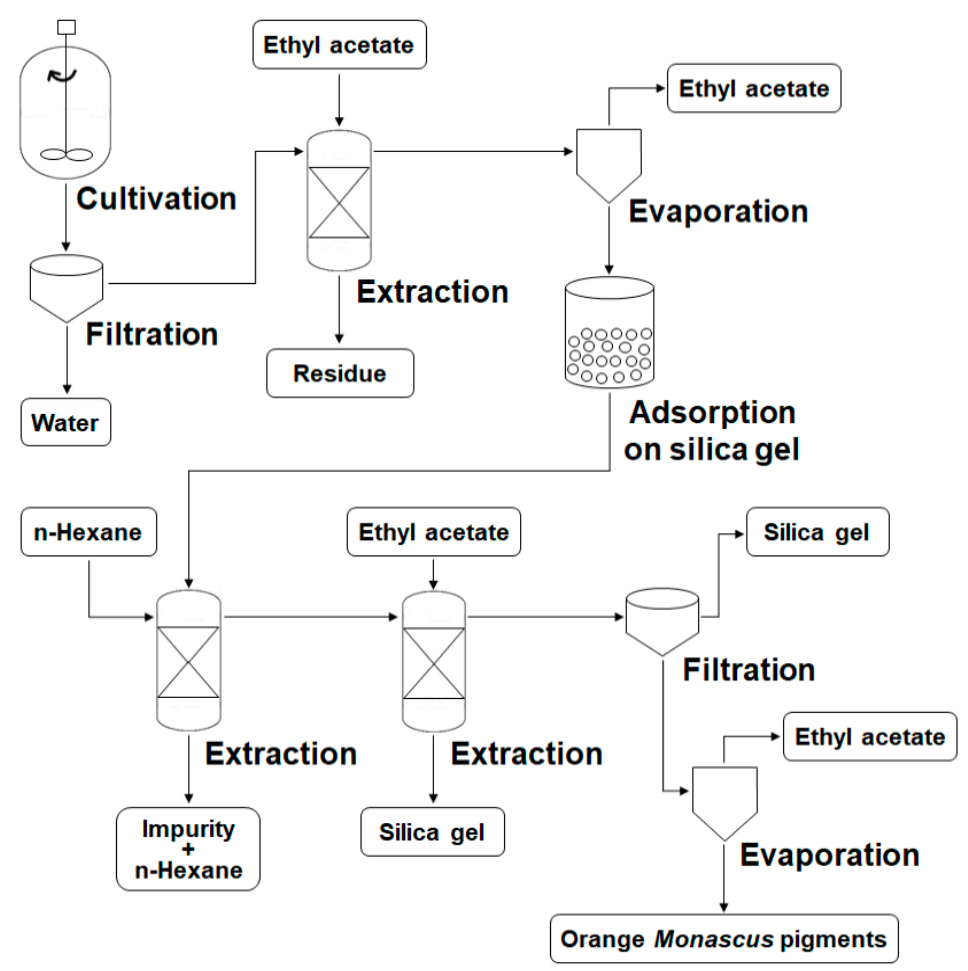

Figure 3. Process flow diagram for the separation and purification of orange Monascus pigments.

After extraction of orange pigments from the filter cakes, the color of the ethyl acetate changed from transparent to dark red, indicating that the orange pigments were already dissolved in the solvent. Undissolved culture debris was discarded to improve the purity of the pigments, and the resulting solution was condensed by evaporation. For further purification, the condensed solution was mixed with silica gel, and a pigment-silica gel complex with dark red color was obtained. To remove hydrophobic impurities from the orange pigments, the pigment-silica gel complex was extracted by n-hexane, a lipophilic volatile organic solvent that could dissolve undesirable hydrophobic substances but poorly extract orange pigments [28]. After completion of the n-hexane extraction, pure ethyl acetate was again used to obtain an orange pigment solution with enhanced purity from the pigment-silica gel complex. The silica gel remaining in the orange pigment solution was eliminated by filtration, and the ethyl acetate was evaporated during the condensing process. The purified orange pigments were then obtained in solid form.

The purified orange pigments were used as the basic building blocks for the synthesis of many types of Monascus pigment derivatives. As shown in Figure 1a, each derivative was synthesized by aminophilic reaction, in which the pyranyl oxygen in the orange pigments was replaced with the nitrogen of the amino group of primary amines or amino acids $[28,30]$. This synthetic method can induce the production of diverse Monascus pigment derivatives with novel molecular structures and increase the possibility of each derivative having different functionalities, such as antimicrobial, antiviral, anticholesterol, antiobesity, and antimelanogenesis effects [31,58]. In addition to these functional effects, 21 amines and 20 amino acids were added to the orange pigments to obtain anti-inflammatory effects, leading to the synthesis of 41 derivatives (Table 1 ).

\subsection{NO Production and Cytotoxicity of Monascus Pigment Derivatives in Raw 264.7 Cells}

Measurement of nitric oxide (NO) levels is a common method for assessing the anti-inflammatory capabilities of bioactive compounds. NO is secreted by macrophages (e.g., Raw 264.7 cells) when exposed to inflammatory stimuli such as lipopolysaccharide (LPS) embedded in the outer membrane of Gram-negative bacteria [17,59]. Suppression of LPS-induced NO production in Raw 264.7 cells 
is considered evidence of potential anti-inflammatory capability. In other words, the lower the NO level in treated cells, the higher the anti-inflammatory activity of the compound. To evaluate the anti-inflammatory effects of Monascus pigment derivatives synthesized in this research, the NO levels in Raw 264.7 cells after exposure were determined and compared.

The NO production of cells treated with the 21 amine derivatives was $48.8-90.2 \%$ when the NO level of LPS-stimulated cells (control cells) with orange Monascus pigments was set to $100 \%$ (Table 2). In particular, the NO levels of cells treated with D2, D5, D8, D14, D15, D16, D19, and D20 derivatives showed statistically significant differences compared to the control cells. However, the D5, D8, D14, D15, D16, D19, and D20 derivatives exhibited statistically low cell viability (Table 2). This indicates that their low NO production was caused by the cytotoxicity. Similar tests were performed on the 20 amino acid derivatives, which resulted in an NO production of $84.3-147.2 \%$. The NO levels of cells treated with amino acid derivatives were not statistically different from the control cells. This does not indicate that amino acid derivatives have no anti-inflammatory effect. Rather, this shows that their NO inhibitory effects are similar to those of orange Monascus pigments, which are known to have anti-inflammatory effects $[60,61]$. The NO inhibitory effects of these amine and amino acid derivatives are due to the azaphilone skeleton. Previous studies reported that Monascus pigments with the azaphilone structure showed anti-inflammatory activities [22,60]. Specifically, azaphilone Monascus pigments have been shown to exhibit much stronger anti-inflammatory effects than non-azaphilone Monascus pigments [62]. Based on our results and previously published data, we conclude that amine and amino acid derivatives with the azaphilone skeleton have anti-inflammatory properties.

Table 2. Nitric oxide (NO) production and cell viability of amine and amino acid derivatives in Raw 264.7 cells.

\begin{tabular}{|c|c|c|c|c|c|}
\hline $\begin{array}{c}\text { Amine } \\
\text { Derivative }\end{array}$ & $\begin{array}{l}\text { NO Production } \\
(\%)\end{array}$ & $\begin{array}{c}\text { Cell Viability } \\
(\%)\end{array}$ & $\begin{array}{l}\text { Amino Acid } \\
\text { Derivative }\end{array}$ & $\begin{array}{c}\text { NO Production } \\
(\%)\end{array}$ & $\begin{array}{c}\text { Cell Viability } \\
(\%)\end{array}$ \\
\hline Con & $100.0 \pm 7.1$ & $100.0 \pm 3.8$ & Con & $100.0 \pm 4.9$ & $100.0 \pm 4.0$ \\
\hline D1 & $64.6 \pm 3.4$ & $53.9 \pm 1.0$ * & D22 & $143.0 \pm 4.7^{*}$ & $94.0 \pm 5.5$ \\
\hline D2 & $51.6 \pm 0.9 *$ & $89.7 \pm 8.4$ & D23 & $106.9 \pm 2.3$ & $84.9 \pm 6.4$ \\
\hline D3 & $56.2 \pm 0.5$ & $31.3 \pm 6.7$ * & D24 & $147.2 \pm 6.1 *$ & $86.3 \pm 5.6$ \\
\hline D4 & $61.2 \pm 2.0$ & $12.9 \pm 1.6^{*}$ & D25 & $100.6 \pm 3.6$ & $93.8 \pm 2.6$ \\
\hline D5 & $56.2 \pm 3.1^{*}$ & $58.4 \pm 5.1$ * & D26 & $135.2 \pm 6.6^{*}$ & $91.2 \pm 5.0$ \\
\hline D6 & $65.1 \pm 2.0$ & $13.5 \pm 4.7^{*}$ & D27 & $106.6 \pm 18.1$ & $103.2 \pm 5.3$ \\
\hline D7 & $70.8 \pm 1.7$ & $3.5 \pm 1.2 *$ & D28 & $126.6 \pm 5.2$ & $96.4 \pm 15.8$ \\
\hline D8 & $48.8 \pm 0.5^{*}$ & $70.9 \pm 3.0 *$ & D29 & $103.1 \pm 5.0$ & $104.0 \pm 6.3$ \\
\hline D9 & $66.2 \pm 2.9$ & $2.4 \pm 1.0$ * & D30 & $105.5 \pm 2.2$ & $112.0 \pm 4.5$ \\
\hline D10 & $90.2 \pm 2.5$ & $2.5 \pm 1.5^{*}$ & D31 & $95.8 \pm 3.0$ & $104.5 \pm 0.8$ \\
\hline D11 & $63.6 \pm 11.4$ & $73.3 \pm 1.1$ * & D32 & $126.4 \pm 4.2 *$ & $90.6 \pm 8.8$ \\
\hline D12 & $73.3 \pm 24.3$ & $86.7 \pm 5.4$ & D33 & $97.3 \pm 6.0$ & $103.5 \pm 4.9$ \\
\hline D13 & $73.5 \pm 15.4$ & $60.4 \pm 8.1$ & D34 & $141.7 \pm 17.6$ & $97.8 \pm 2.1$ \\
\hline D14 & $55.6 \pm 2.4^{*}$ & $23.4 \pm 4.9$ * & D35 & $103.0 \pm 11.4$ & $109.0 \pm 4.5$ \\
\hline D15 & $55.9 \pm 3.3^{*}$ & $63.7 \pm 2.2$ * & D36 & $137.3 \pm 16.3$ & $102.6 \pm 1.0$ \\
\hline D16 & $56.8 \pm 2.9 *$ & $16.3 \pm 2.9$ * & D37 & $100.9 \pm 2.3$ & $104.7 \pm 7.0$ \\
\hline D17 & $60.3 \pm 11.3$ & $44.5 \pm 7.3^{*}$ & D38 & $118.3 \pm 4.8$ & $101.3 \pm 3.4$ \\
\hline D18 & $74.8 \pm 5.7$ & $12.0 \pm 6.7$ * & D39 & $100.3 \pm 7.6$ & $108.0 \pm 2.9$ \\
\hline D19 & $56.2 \pm 4.0^{*}$ & $9.6 \pm 1.0 *$ & D40 & $136.7 \pm 13.7$ & $93.7 \pm 4.3$ \\
\hline D20 & $58.2 \pm 2.6^{*}$ & $6.3 \pm 3.4 *$ & D41 & $84.3 \pm 4.4$ & $98.4 \pm 3.3$ \\
\hline D21 & $66.1 \pm 3.1$ & $7.3 \pm 3.2 *$ & & & \\
\hline
\end{tabular}

One-way ANOVA followed by Tukey's HSD and Games-Howell post-hoc tests were performed. Values are the mean \pm SEM $(n=3) .\left(^{*}\right) p<0.05$ indicates significant differences compared to the control group. In the case of NO production, cells were treated with lipopolysaccharide (LPS) $(10 \mu \mathrm{g} / \mathrm{mL})$ in the presence or absence of Monascus pigment derivatives $(20 \mu \mathrm{M})$. Con = LPS-stimulated control cells with orange Monascus pigments. In the case of cell viability, cells were treated with or without Monascus pigment derivatives $(20 \mu \mathrm{M})$. Con = control cells treated with orange Monascus pigments. 
Despite having the same azaphilone structure, the amine derivatives showed a higher efficacy in suppressing NO production than amino acid derivatives (Table 2). This difference was likely caused by the amines and amino acids used for the synthesis of the Monascus pigment derivatives. Unlike amino acids, most amine compounds contain structures such as pyridine, triazole, and phenyl rings, which may contribute to increased anti-inflammatory effects. Flavonoids, including anthocyanins, catechins, flavones, isoflavones, and flavonols, consist of multiple phenyl groups and are widely recognized as natural anti-inflammatory agents $[63,64]$. We suggest that the combination of the azaphilone skeleton-containing orange Monascus pigments and the ring structure-containing amines into the amine derivatives leads to higher anti-inflammatory effects compared to the amino acid derivatives.

To determine their potential application as anti-inflammatory food colorants, the toxicity of the amine and amino acid derivatives was tested for safety. To assess cytotoxicity, cell viability was determined using the MTT assay with Raw 264.7 cells. Most of the amine derivatives showed low cell viabilities at $20 \mu \mathrm{M}$ concentration, which was used to inhibit NO production (Table 2). Compared to the control cells treated with orange Monascus pigments, a decrease in cell viability of less than $80 \%$ was observed in 19 of the 21 amine derivatives, indicating that most of the amine derivatives were toxic to Raw 264.7 cells. However, two amine derivatives, D2 and D12, and the 20 amino acid derivatives showed high cell viabilities ( $>80 \%$ ), indicating their negligible cytotoxicity (Table 2 ). It is worthwhile to mention that these cell viability data are opposite to our previous results [39] for cytotoxicity, where cell viabilities were $87-92 \%$ when 4-phenylbutylamine derivatives were treated to 3T3-L1. It is possible that a different cell was used for tests with a different target (3T3-L1 cell for lipid adipocyte vs. Raw 264.7 cell for nitric oxide production) that showed a different cell viability.

As previously described, the amino acid derivatives were synthesized by the addition of amino acids, which are naturally produced organic compounds within the cells of living organisms. The 19 amino acids, except theanine (D41), are known to be key molecules for building proteins (Table 1). Owing to their low toxicity, origin, and role, amino acids are considered as GRAS [65]. The high safety of amino acids was probably imparted to the amino acid Monascus pigment derivatives, contributing to their high cell viabilities. In contrast to amino acids, the amines used for the synthesis of the amine derivatives are mainly synthesized through artificial chemical reactions and are not natural compounds found in living organisms. For this reason, amines generally have high toxicity. This toxicity was apparently imparted to the amine derivatives, resulting in low cell viability. However, some amine derivatives are not toxic at low administration levels. As reported in our previous study, two amine derivatives of the Monascus pigment, (R)-(+)-1-(1-naphtyl)-ethylamine and 4-phenylbutylamine, showed high cell viabilities $(>80 \%)$ in 3T3-L1 cells up to $25 \mu \mathrm{M}$ concentration [39]. Similarly, in this study, one amine derivative, D2, also exhibited high cell viability $(89.7 \%)$ in Raw 264.7 cells. Considering these results, we conclude that the D2 derivative has the potential for use due to its high anti-inflammatory activity and low cytotoxicity.

\subsection{Inhibition of iNOS Expression in the Concentration of Amine Derivatives}

Based on NO inhibitory activity and cell viability screening, the D2 derivative was selected. The D2 derivative showed statistically significant NO inhibitory activity $(48.4 \%)$ and its cytotoxicity (89.7\% cell viability) was not statistically different from the control cells (Table 2). To further evaluate its anti-inflammatory activity, the expression levels of iNOS were investigated by Western blot analysis. iNOS catalyzes NO formation from molecular oxygen $\left(\mathrm{O}_{2}\right)$ and arginine [66], and it plays a role in regulating the release of NO [67]. Thus, suppression of LPS-induced iNOS expression is considered a potential anti-inflammatory effect.

As shown in Figure 4, iNOS was predominantly expressed in the LPS-stimulated Raw 264.7 cells without the D2 derivative, whereas expression was gradually reduced with increasing concentration of the D2 derivative. This indicates that the D2 derivative suppresses LPS-induced iNOS expression in a dose-dependent manner. In the case of the D2 derivative, the inhibition of iNOS expression began at a concentration of $2.5 \mu \mathrm{M}$ and was almost completely suppressed at a concentration of $20 \mu \mathrm{M}$. This result 
is in agreement with previous results that showed that the D2 derivative has high cell viability and significantly inhibited NO production (Table 2). Considering an association between NO production and iNOS, we suggest that the inhibitory effect of the D2 derivative against NO production resulted from their iNOS suppression.

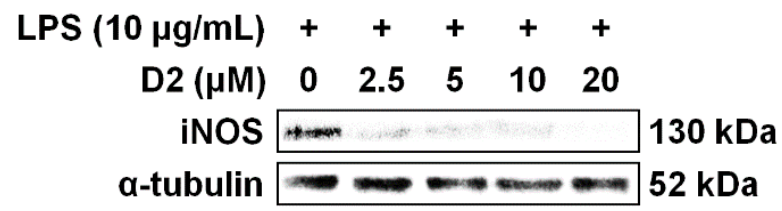

Figure 4. Concentration-dependent inhibitory effects of the 2-amino-4-picoline (D2) derivative of Monascus pigment on expression of inducible nitric oxide synthase (iNOS) in Raw 264.7 cells stimulated with lipopolysaccharide (LPS).

Similar to the D2 derivative, there are several reports of iNOS inhibition by other Monascus pigments. Monaphilone A and ankaflavin (yellow pigments), which are extracted from red mold rice, decreased iNOS expression at a concentration of $10 \mu \mathrm{M}$ [68]. Furthermore, monaphilones $\mathrm{A}$ and $\mathrm{B}$ (yellow pigments) and monaphilols A-D (orange pigments), which were isolated from red mold rice and red mold dioscorea, respectively, suppressed iNOS expression at concentrations of 30 and $5 \mu \mathrm{M}$, respectively [61]. These Monascus pigments, like the D2 derivative, have azaphilone skeletons. Their structural commonality perhaps contributed to the inhibition of iNOS expression. On the other hand, despite having similar inhibitory effects, their colors are different (e.g., yellow and orange pigments). This variety of colors has practical implications for their application range as food colorants. Notably, because the D2 derivative is a Monascus pigment with red color, it has the potential to serve as a food colorant that could replace existing red pigments. To the best of our knowledge, no red pigments previously reported among Monascus pigments have anti-inflammatory properties. Therefore, the D2 derivative, which is characterized by a red color, high cell viability, and anti-inflammatory activity, could be used as a functional food colorant for the prevention and treatment of chronic inflammation.

\section{Conclusions}

Orange Monascus pigments were produced through submerged fermentation in a $5 \mathrm{~L}$ bioreactor. During the fermentation process, the use of ammonium nitrate as a nitrogen source resulted in low $\mathrm{pH}$ values, which increased the total yield of orange pigments by inhibiting the production of undesired red and yellow pigments. After separation and purification processes using ethyl acetate, n-hexane, and silica gel, 41 different Monascus pigment derivatives were synthesized from purified orange pigments by aminophilic reaction with 21 amines and 20 amino acids. Among the derivatives, one amine derivative, D2, significantly inhibited NO production and had little effect on cell viability. In addition, the D2 derivative suppressed iNOS expression in a concentration-dependent manner, indicating that it has anti-inflammatory properties. These results show that anti-inflammatory properties can be improved by structural modification (derivatization) of orange Monascus pigments with amines or amino acids.

Author Contributions: Conceptualization, D.C., S.M.S., C.S.S. and S.K.; Methodology, D.C. and S.M.S.; Investigation, D.C., S.M.S., H.J.A. and C.S.S.; Data analysis, D.C., S.M.S., D.K. and S.K.; Writing-original draft preparation, D.C. and S.M.S.; Writing-review and editing, T.V.J., H.J.A., D.K. and S.K.; Visualization, D.C., S.M.S. and S.K.; Supervision, D.K., T.V.J. and S.K.; Funding acquisition, D.C., C.S.S., T.V.J., D.K. and S.K. All authors have read and agreed to the published version of the manuscript.

Funding: This research was supported by the Basic Science Research Program of the National Research Foundation of Korea (NRF), funded by the Ministry of Education (2017R1A6A3A11029462). This work was also supported by the Faculty Research and Creative Activity Committee (FRCAC) grant (No. 221745) and an Office of Research and Sponsored Programs (ORSP) grant for the postdoc researcher recruitment funded by Middle Tennessee State University (MTSU). The Maryland E-Nnovation Initiative Fund (MEIF) administered by the Maryland Department of Commerce supported the research of Daehwan Kim. 
Conflicts of Interest: The authors declare no conflict of interest.

\section{References}

1. Takeuchi, O.; Akira, S. Pattern recognition receptors and inflammation. Cell 2010, 140, 805-820. [CrossRef]

2. Medzhitov, R. Origin and physiological roles of inflammation. Nature 2008, 454, 428-435. [CrossRef] [PubMed]

3. Ji, R.R.; Xu, Z.Z.; Gao, Y.J. Emerging targets in neuroinflammation-driven chronic pain. Nat. Rev. Drug Discov. 2014, 13, 533-548. [CrossRef] [PubMed]

4. Ji, R.R.; Chamessian, A.; Zhang, Y.Q. Pain regulation by non-neuronal cells and inflammation. Science 2016, 354, 572-577. [CrossRef] [PubMed]

5. Nathan, C.; Ding, A. Nonresolving inflammation. Cell 2010, 140, 871-882. [CrossRef] [PubMed]

6. Wang, D.; DuBois, R.N. Immunosuppression associated with chronic inflammation in the tumor microenvironment. Carcinogenesis 2015, 36, 1085-1093. [CrossRef] [PubMed]

7. Lee, Y.J.; Park, S.J.; Yun, K.S.; Kang, J.Y.; Lee, S.H. Enzymeless glucose sensor integrated with chronically implantable nerve cuff electrode for in-situ inflammation monitoring. Sens. Actuators B Chem. 2016, 222, 425-432. [CrossRef]

8. Mazarakis, N.; Snibson, K.; Licciardi, P.V.; Karagiannis, T.C. The potential use of L-sulforaphane for the treatment of chronic inflammatory diseases: A review of the clinical evidence. Clin. Nutr. 2020, 39, 664-675. [CrossRef]

9. Bennett, J.M.; Reeves, G.; Billman, G.E.; Sturmberg, J.P. Inflammation-nature's way to efficiently respond to all types of challenges: Implications for understanding and managing "the epidemic" of chronic diseases. Front. Med. 2018, 5, 316. [CrossRef]

10. Ginwala, R.; Bhavsar, R.; Chigbu, D.I.; Jain, P.; Khan, Z.K. Potential role of flavonoids in treating chronic inflammatory diseases with a special focus on the anti-inflammatory activity of apigenin. Antioxidants 2019, 8, 35. [CrossRef]

11. Lee, S.Y.; Cho, S.S.; Li, Y.; Bae, C.S.; Park, K.M.; Park, D.H. Anti-inflammatory effect of Curcuma longa and Allium hookeri co-treatment via NF-кB and COX-2 pathways. Sci. Rep. 2020, 10, 5718. [CrossRef] [PubMed]

12. Rhen, T.; Cidlowski, J.A. Antiinflammatory action of glucocorticoids-New mechanisms for old drugs. N. Engl. J. Med. 2005, 353, 1711-1723. [CrossRef] [PubMed]

13. Haß, U.; Herpich, C.; Norman, K. Anti-inflammatory diets and fatigue. Nutrients 2019, 11, 2315. [CrossRef] [PubMed]

14. Kontogiorgis, C.A.; Bompou, E.M.; Ntella, M.; Berghe, W.V. Natural products from Mediterranean diet: From anti-inflammatory agents to dietary epigenetic modulators. Anti-Inflamm. Anti-Allergy Agents Med. Chem. 2010, 9, 101-124. [CrossRef]

15. Hoffman, R.; Gerber, M. Food processing and the Mediterranean diet. Nutrients 2015, 7, 7925-7964. [CrossRef]

16. Cheng, S.C.; Wu, Y.H.; Huang, W.C.; Pang, J.S.; Huang, T.H.; Cheng, C.Y. Anti-inflammatory property of quercetin through downregulation of ICAM-1 and MMP-9 in TNF- $\alpha$-activated retinal pigment epithelial cells. Cytokine 2019, 116, 48-60. [CrossRef]

17. Ahn, H.J.; You, H.J.; Park, M.S.; Li, Z.; Choe, D.; Johnston, T.V.; Ku, S.; Ji, G.E. Microbial biocatalysis of quercetin-3-glucoside and isorhamnetin-3-glucoside in Salicornia herbacea and their contribution to improved anti-inflammatory activity. RSC Adv. 2020, 10, 5339-5350. [CrossRef]

18. Sreedhar, R.; Arumugam, S.; Thandavarayan, R.A.; Karuppagounder, V.; Watanabe, K. Curcumin as a therapeutic agent in the chemoprevention of inflammatory bowel disease. Drug Discov. Today 2016, 21, 843-849. [CrossRef]

19. Ran, Z.; Zhang, Y.; Wen, X.; Ma, J. Curcumin inhibits high glucose-induced inflammatory injury in human retinal pigment epithelial cells through the ROS-PI3K/AKT/mTOR signaling pathway. Mol. Med. Rep. 2019, 19, 1024-1031. [CrossRef]

20. Rodriguez-Amaya, D.B. Update on natural food pigments-A mini-review on carotenoids, anthocyanins, and betalains. Food Res. Int. 2019, 124, 200-205. [CrossRef]

21. Eker, M.E.; Aaby, K.; Budic-Leto, I.; Brnčić, S.R.; El, S.N.; Karakaya, S.; Simsek, S.; Manach, C.; Wiczkowski, W.; Pascual-Teresa, S. A review of factors affecting anthocyanin bioavailability: Possible implications for the inter-individual variability. Foods 2020, 9, 2. [CrossRef] [PubMed] 
22. Wu, H.C.; Cheng, M.J.; Wu, M.D.; Chen, J.J.; Chen, Y.L.; Chang, H.S. Three new constituents from the fungus of Monascus purpureus and their anti-inflammatory activity. Phytochem. Lett. 2019, 31, 242-248. [CrossRef]

23. Lin, C.H.; Lin, T.H.; Pan, T.M. Alleviation of metabolic syndrome by monascin and ankaflavin: The perspective of Monascus functional foods. Food Funct. 2017, 8, 2102-2109. [CrossRef]

24. Chen, W.; He, Y.; Zhou, Y.; Shao, Y.; Feng, Y.; Li, M.; Chen, F. Edible filamentous fungi from the species Monascus: Early traditional fermentations, modern molecular biology, and future genomics. Compr. Rev. Food Sci. Food Saf. 2015, 14, 555-567. [CrossRef]

25. Zhou, W.; Guo, R.; Guo, W.; Hong, J.; Li, L.; Ni, L.; Sun, J.; Liu, B.; Rao, P.; Lv, X. Monascus yellow, red and orange pigments from red yeast rice ameliorate lipid metabolic disorders and gut microbiota dysbiosis in Wistar rats fed on a high-fat diet. Food Funct. 2019, 10, 1073-1084. [CrossRef]

26. Mapari, S.A.S.; Thrane, U.; Meyer, A.S. Fungal polyketide azaphilone pigments as future natural food colorants? Trends Biotechnol. 2010, 28, 300-307. [CrossRef]

27. Dufossé, L.; Galaup, P.; Yaron, A.; Arad, S.M.; Blanc, P.; Chidambara Murthy, K.N.; Ravishankar, G.A. Microorganisms and microalgae as sources of pigments for food use: A scientific oddity or an industrial reality. Trends Food Sci. Technol. 2005, 16, 389-406. [CrossRef]

28. Jia, L.; Tu, X.; He, K.; Wang, C.; Yin, S.; Zhou, Y.; Chen, W. Monascorubrin and rubropunctatin: Preparation and reaction characteristics with amines. Dyes Pigm. 2019, 170, 107629. [CrossRef]

29. Chen, W.; Chen, R.; Liu, Q.; He, Y.; He, K.; Ding, X.; Kang, L.; Guo, X.; Xie, N.; Zhou, Y.; et al. Orange, red, yellow: Biosynthesis of azaphilone pigments in Monascus fungi. Chem. Sci. 2017, 8, 27-4925. [CrossRef]

30. Liu, L.; Zhao, J.; Huang, Y.; Xin, Q.; Wang, Z. Diversifying of chemical structure of native Monascus pigments. Front. Microbiol. 2018, 9, 3143. [CrossRef]

31. Choe, D.; Jung, H.H.; Kim, D.; Shin, C.S.; Johnston, T.V.; Ku, S. In vivo evaluation of the anti-obesity effects of combinations of Monascus pigment derivatives. RSC Adv. 2020, 10, 1456-1462. [CrossRef]

32. Kim, C.; Jung, H.; Kim, Y.O.; Shin, C.S. Antimicrobial activities of amino acid derivatives of monascus pigments. FEMS Microbiol. Lett. 2006, 264, 117-124. [CrossRef] [PubMed]

33. Sun, J.M.; Kim, S.J.; Kim, G.W.; Rhee, J.K.; Kim, N.D.; Jung, H.; Jeun, J.; Lee, S.H.; Han, S.H.; Shin, C.S.; et al. Inhibition of hepatitis $C$ virus replication by Monascus pigment derivatives that interfere with viral RNA polymerase activity and the mevalonate biosynthesis pathway. J. Antimicrob. Chemother. 2012, 67, 49-58. [CrossRef]

34. Jeun, J.; Jung, H.; Kim, J.H.; Kim, Y.O.; Youn, S.H.; Shin, C.S. Effect of the Monascus pigment threonine derivative on regulation of the cholesterol level in mice. Food Chem. 2008, 107, 1078-1085. [CrossRef]

35. Kim, J.H.; Kim, H.J.; Park, H.W.; Youn, S.H.; Choi, D.Y.; Shin, C.S. Development of inhibitors against lipase and $\alpha$-glucosidase from derivatives of Monascus pigment. FEMS Microbiol. Lett. 2007, 276, 93-98. [CrossRef] [PubMed]

36. Jang, H.; Choe, D.; Shin, C.S. Novel derivatives of Monascus pigment having a high CETP inhibitory activity. Nat. Prod. Res. 2014, 28, 1427-1431. [CrossRef]

37. Nam, K.; Choe, D.; Shin, C.S. Antiobesity effect of a jelly food containing the L-tryptophan derivative of Monascus pigment in mice. J. Funct. Foods 2014, 9, 306-314. [CrossRef]

38. Jo, D.; Choe, D.; Nam, K.; Shin, C.S. Biological evaluation of novel derivatives of the orange pigments from Monascus sp. as inhibitors of melanogenesis. Biotechnol. Lett. 2014, 36, 1605-1613. [CrossRef]

39. Choe, D.; Lee, J.; Woo, S.; Shin, C.S. Evaluation of the amine derivatives of Monascus pigment with anti-obesity activities. Food Chem. 2012, 134, 315-323. [CrossRef]

40. Choe, D.; Jang, H.; Jung, H.H.; Shin, C.S.; Johnston, T.V.; Kim, D.; Ku, S. In vivo anti-obesity effects of Monascus pigment threonine derivative with enhanced hydrophilicity. J. Funct. Foods 2020, 67, 103849. [CrossRef]

41. Vendruscolo, F.; Schmidell, W.; de Oliveira, D.; Ninow, J.L. Kinetic of orange pigment production from Monascus ruber on submerged fermentation. Bioprocess Biosyst. Eng. 2017, 40, 115-121. [CrossRef] [PubMed]

42. Pereira, D.G.; Tonso, A.; Kilikian, B.V. Effect of dissolved oxygen concentration on red pigment and citrinin production by Monascus purpureus ATCC 36928. Braz. J. Chem. Eng. 2008, 25, 247-253. [CrossRef]

43. Hajjaj, H.; Blanc, P.J.; Groussac, E.; Goma, G.; Uribelarrea, J.L.; Loubiere, P. Improvement of red pigment/ citrinin production ratio as a function of environmental conditions by monascus ruber. Biotechnol. Bioeng. 1999, 64, 497-501. [CrossRef]

44. Feng, Y.; Shao, Y.; Chen, F. Monascus pigments. Appl. Microbiol. Biotechnol. 2012, 96, 1421-1440. [CrossRef] 
45. Li, M.; Kang, L.; Ding, X.; Liu, J.; Liu, Q.; Shao, Y.; Molnár, I.; Chen, F. Monasone naphthoquinone biosynthesis and resistance in Monascus fungi. mBio 2020, 11, e02676-19. [CrossRef]

46. Chen, W.; Feng, Y.; Molnár, I.; Chen, F. Nature and nurture: Confluence of pathway determinism with metabolic and chemical serendipity diversifies Monascus azaphilone pigments. Nat. Prod. Rep. 2019, 36, 561-572. [CrossRef]

47. Carels, M.; Shepherd, D. The effect of different nitrogen sources on pigment production and sporulation of Monascus species in submerged, shaken culture. Can. J. Microbiol. 1977, 23, 1360-1372. [CrossRef]

48. Patrovsky, M.; Sinovska, K.; Branska, B.; Patakova, P. Effect of initial pH, different nitrogen sources, and cultivation time on the production of yellow or orange Monascus purpureus pigments and the mycotoxin citrinin. Food Sci. Nutr. 2019, 7, 3494-3500. [CrossRef]

49. Chen, M.H.; Johns, M.R. Effect of $\mathrm{pH}$ and nitrogen source on pigment production by Monascus purpureus. Appl. Microbiol. Biotechnol. 1993, 40, 132-138. [CrossRef]

50. Li, L.; Chen, S.; Gao, M.; Ding, B.; Zhang, J.; Zhou, Y.; Liu, Y.; Yang, H.; Wu, Q.; Chen, F. Acidic conditions induce the accumulation of orange Monascus pigments during liquid-state fermentation of Monascus ruber M7. Appl. Microbiol. Biotechnol. 2019, 103, 8393-8402. [CrossRef]

51. Shi, K.; Song, D.; Chen, G.; Pistolozzi, M.; Wu, Z.; Quan, L. Controlling composition and color characteristics of Monascus pigments by $\mathrm{pH}$ and nitrogen sources in submerged fermentation. J. Biosci. Bioeng. 2015, 120, 145-154. [CrossRef] [PubMed]

52. Shi, K.; Chen, G.; Pistolozzi, M.; Xia, F.; Wu, Z. Improved analysis of Monascus pigments based on their $\mathrm{pH}$-sensitive Uv-Vis absorption and reactivity properties. Food Addit. Contam. Part A Chem. Anal. Control Expo. Risk Assess. 2016, 33, 1396-1401. [CrossRef]

53. Agboyibor, C.; Kong, W.B.; Chen, D.; Zhang, A.M.; Niu, S.-Q. Monascus pigments production, composition, bioactivity and its application: A review. Biocatal. Agric. Biotechnol. 2018, 16, 433-447. [CrossRef]

54. Sachindra, N.M.; Bhaskar, N.; Mahendrakar, N.S. Recovery of carotenoids from shrimp waste in organic solvents. Waste Manag. 2006, 26, 1092-1098. [CrossRef] [PubMed]

55. Lu, F.; Liu, L.; Huang, Y.; Zhang, X.; Wang, Z. Production of Monascus pigments as extracellular crystals by cell suspension culture. Appl. Microbiol. Biotechnol. 2018, 102, 677-687. [CrossRef]

56. Zhao, G.P.; Li, Y.Q.; Yang, J.; Cui, K.Y. Antibacterial characteristics of orange pigment extracted from Monascus pigments against Escherichia coli. Czech J. Food Sci. 2016, 34, 197-203. [CrossRef]

57. Lee, S.J.; McClements, D.J. Fabrication of protein-stabilized nanoemulsions using a combined homogenization and amphiphilic solvent dissolution/evaporation approach. Food Hydrocoll. 2010, 24, 560-569. [CrossRef]

58. Kim, D.; Ku, S. Beneficial effects of Monascus sp. KCCM 10093 pigments and derivatives: A mini review. Molecules 2018, 23, 98. [CrossRef]

59. Brannan, C.A.; Roberts, M.R. Resident microglia from adult mice are refractory to nitric oxide-inducing stimuli due to impaired NOS2 gene expression. Glia 2004, 48, 120-131. [CrossRef]

60. Hsu, Y.W.; Hsu, L.C.; Liang, Y.H.; Kuo, Y.H.; Pan, T.M. New bioactive orange pigments with yellow fluorescence from Monascus-fermented dioscorea. J. Agric. Food Chem. 2011, 59, 4512-4518. [CrossRef]

61. Hsu, L.C.; Liang, Y.H.; Hsu, Y.W.; Kuo, Y.H.; Pan, T.M. Anti-inflammatory properties of yellow and orange pigments from Monascus purpureus NTU 568. J. Agric. Food Chem. 2013, 61, 2796-2802. [CrossRef] [PubMed]

62. Akihisa, T.; Tokuda, H.; Yasukawa, K.; Ukiya, M.; Kiyota, A.; Sakamoto, N.; Suzuki, T.; Tanabe, N.; Nishino, H. Azaphilones, furanoisophthalides, and amino acids from the extracts of Monascus pilosus-fermented rice (red-mold rice) and their chemopreventive effects. J. Agric. Food Chem. 2005, 53, 562-565. [CrossRef] [PubMed]

63. Valls, J.; Millán, S.; Martí, M.P.; Borràs, E.; Arola, L. Advanced separation methods of food anthocyanins, isoflavones and flavanols. J. Chromatogr. A 2009, 1216, 7143-7172. [CrossRef] [PubMed]

64. Serafini, M.; Peluso, I.; Raguzzini, A. Flavonoids as anti-inflammatory agents. Proc. Nutr. Soc. 2010, 69, 273-278. [CrossRef]

65. Zhu, S.; Gao, H.; Babu, S.; Garad, S. Co-amorphous formation of high-dose zwitterionic compounds with amino acids to improve solubility and enable parenteral delivery. Mol. Pharm. 2018, 15, 97-107. [CrossRef] [PubMed]

66. Lin, Y.L.; Tsai, S.H.; Lin-Shiau, S.Y.; Ho, C.T.; Lin, J.K. Theaflavin-3,3'-digallate from black tea blocks the nitric oxide synthase by down-regulating the activation of NF-kB in macrophages. Eur. J. Pharmacol. 1999, 367, 379-388. [CrossRef] 
67. Pereira-Suárez, A.L.; Estrada-Chávez, C.; Arriaga-Díaz, C.; Espinosa-Cueto, P.; Mancilla, R. Coexpression of NRAMP1, iNOS, and nitrotyrosine in bovine tuberculosis. Vet. Pathol. 2006, 43, 709-717. [CrossRef]

68. Hsu, L.C.; Hsu, Y.W.; Liang, Y.H.; Kuo, Y.H.; Pan, T.M. Anti-tumor and anti-inflammatory properties of ankaflavin and monaphilone A from Monascus purpureus NTU 568. J. Agric. Food Chem. 2011, 59, 1124-1130. [CrossRef]

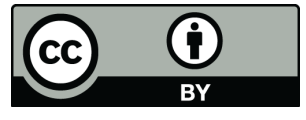

(C) 2020 by the authors. Licensee MDPI, Basel, Switzerland. This article is an open access article distributed under the terms and conditions of the Creative Commons Attribution (CC BY) license (http://creativecommons.org/licenses/by/4.0/). 